MATYLDA CHRZASZCZ

Uniwersytet Jagielloński w Krakowie

e-mail: matylda.chrzaszcz@uj.edu.pl

\title{
Rzecz w procesie dojrzewania. Zielony namiot Ludmiły Ulickiej
}

\author{
Abstract \\ An Object in a Human Development to Maturity. The Big Green Tent \\ by Ludmila Ulitskaya
}

The article concerns very typical issues of Ludmila Ulitskaya's prose, namely childhood and maturity as well as relationship between human and things (objects).

In the novel entitled The Big Green Tent the process of moral development is described. It involves, among other things, sudden events of crucial and initiatory character, which have the features of special ritual. During rituals the heroes are submitted to physical and mental resilience tests.

There are some objects inherent to heroes' initiation. In the novel they go beyond the inanimate matter, which is passive and submitted to human will. They are personified, have their own history and what is most important they are the driving force, the initiators of turning points which affect heroes' future. Those objects are: a camera, skates and a knife.

Revealing the objects' "agency" is one of main aims of the article. Agency of above mentioned objects manifests itself by the way they influence heroes' behavior, interfere in their future and play significant role in heroes' development to maturity.

Keywords: Ludmila Ulitskaya, The Big Green Tent, maturity, object, objects agency.

Słowa kluczowe: Ludmila Ulitskaya, Zielony namiot, dojrzałość, przedmiot, sprawczość przedmiotów.

Pęknięta porcelanowa czarka, stłuczony chiński serwis do herbaty, babcine giemzowe rękawiczki, zniszczony koszyk, tarcza gimnazjalna, kawałek ceratowej wstążeczki z kliniki położniczej - wszystkie te rzeczy niegdyś do kogoś należały i czemuś służyły, z czasem jednak utraciły swoją użyteczność, a mimo to wciąż trwały. Ich stan wykluczał możliwość posługiwania się nimi zgodnie z przypisanymi im funkcjami, a mimo to przez lata były starannie i troskliwie przechowywane - z nadzieją, że w przyszłości uda się za ich pośrednictwem odbudować więź z tym, co minione. Naprawa starych, zniszczonych i bezużytecznych rzeczy miała wprowadzić ład w przeszłość po to, by bez przeszkód zanurzyć się w teraźniejszości. Pudełko pełne przedmiotów cennych, choć pozbawionych jakiejkolwiek wartości 
materialnej, towarzyszyło Ludmile Ulickiej wiernie przez trzydzieści lat, aż wreszcie wraz z zawartością wylądowało na śmietniku. Jego milcząca obecność przez tak długi czas stała się dla właścicielki nieznośnym balastem, a ciągłe odkładanie porządkowania swojej przeszłości okazało się na tyle dokuczliwe, że łatwiej było szybko i nieodwracalnie odciąć się od niej. Rozstanie z tak długo hołubionymi rzeczami na chwilę rzeczywiście przyniosło ulgę i poczucie wolności, jednak uczucia te okazały się złudne i krótkotrwałe. W naturze rzeczy kryje się bowiem zdolność głębokiej ingerencji w sferę psychiczną człowieka. To, co materialne, jest silnie związane z niematerialnym. Zawartość pudełka utkwiła w pamięci jego właścicielki tak mocno, że mimo swojej fizycznej nieobecności wciąż boleśnie kazała doświadczać nieuporządkowanej przeszłości. Pamięć form i barw rzeczy jest według Ulickiej pamięcią o ideach, koncepcjach i zasadach, czyli o tym, z czym rzeczy się kojarzyły i co uosabiały. Niemożność usunięcia z pamięci wszystkich tych ,rupieci" jest tym dotkliwsza, im bardziej rozczarowujące okazały się owe koncepcje i idee z przeszłości. Rzeczy, a ściślej - pamięć o rzeczach jest zatem przekleństwem, ogranicza, krępuje, nie pozwala zapomnieć, odciąć się od niechcianych niematerialnych i minionych aspektów życia - o tym właśnie pisze Ludmiła Ulicka w zbiorze esejów Священный мусор ${ }^{1}$. „Śmieci”, ,,rupiecie”, choć dawno przepadły na wysypisku, wciąż żyją w świadomości człowieka, w jego pamięci, a los tekturowego pudełka jest metaforą odzwierciedlającą proces gromadzenia bogactwa i gorączkowych prób uwolnienia się od niego. „Оказалось, ничего выбросить невозможно. Цепкое сознание не хочет расстаться с побрякушками из стекла, металла, опыта и мыслей, знания и догадок"2.

Священный мусор uświadamia, jak rzeczy, mimo ich pozornej bierności, kształtują psychikę człowieka, wpływają na stan jego świadomości i postrzeganie samego siebie - dowodzą tym samym swojej szczególnej sprawczości. Autorka eseju dostrzega nierozerwalny związek pomiędzy człowiekiem a rzeczą ${ }^{3}$ i sama nie kryje swojego przywiązania do przedmiotów, do ich ,biografii, geografii, narodzin i śmierci" ". To przywiązanie znajduje swój wyraz również w twórczości pisarki. Szczególnie interesujący jest obecny w niej aspekt „biografii”, rzeczy, silnie skorelowanej z biografią ludzi, gdy rzecz staje się czynnikiem determinują-

1 Л. Улицкая, Священный мусор, http://bookz.ru/authors/ludmila-ulickaa/sva6enni_471/page8-sva6enni_471.html (dostęp: 12.02.2017).

${ }^{2}$ Ibid.

${ }^{3}$ Tym samym refleksja autorki zbieżna jest z opiniami współczesnych badaczy zajmujących się tematyką relacji człowiek-rzecz, takich jak S. Pearce czy E. Rohberg-Halton, twierdzących, że nie tyle ludzie stwarzają rzeczy, ile są przez te rzeczy stwarzani, a sposób ich życia jest w dużej mierze kształtowany właśnie przez rzeczy. Zob. J. Barański, Świat rzeczy. Zarys antropologiczny, Kraków 2007, s. $18-19$.

4 Л. Улицкая, op. cit.

${ }^{5}$ Zgodnie z koncepcją biografii rzeczy, która w ostatnich latach zdobywa w naukach humanistycznych coraz większą popularność, badanie życia przedmiotów powinno opierać się na pytaniach podobnych do tych, jakie stawia się, badając ludzkie biografie, np.: w jakim wieku są rzeczy, jak z wiekiem się zmieniają, co działo się z nimi dotychczas i jak kształtują się ich losy po utracie przez nie użyteczności. Zob. A. Rybus, Czy rzecz może być sprawca? Perspektywa humanistyki i nauk spolecznych [w:] Ludzie w świecie przedmiotów. Przedmioty w świecie ludzi, red. A. Rybus, M.W. Kornobis, Warszawa 2016, s. 19-58. 
cym ludzkie życie i nadającym mu określony kierunek, a także stanowi element niezbędny w procesie kształtowania się osobowości człowieka. Dzięki takiemu ujęciu dochodzi do połączenia dwóch znaczących w twórczości pisarki tematów: dzieciństwa i relacji człowieka z rzeczami.

Ulicka podejmuje temat dzieciństwa w wielu utworach, począwszy od opowiadań (Бронька, Ветреная осnа, cykl Девочки, Сонечка [Sonieczka], Счастливые), poprzez powieści (Медея и ее дети [Medea i jej dzieci], Казус Кукуиккого [Przypadek doktora Kukockiego], Зеленьй шатер [Zielony namiot]), a skończywszy na przywoływanym powyżej zbiorze esejów Священный мусор. Wchodzące w jego skład teksty łączy z powieścią Zielony namiot zainteresowanie dzieciństwem jako etapem prowadzącym do przebudzenia się świadomości własnej odrębności, czyli ,ja”, i oddzielenia się owego ,ja” od „nie-ja”. Opierając się na swoich doświadczeniach autorka pisze:

Это пробуждение «я», которым все так дорожат. [...] «Я» - отчасти - обозначается границами нашего персонального опыта. Оно отделяется как твердь от неба. Космогония личности. [...] Человек проживает формирование этой границы между «я» и «не-я» $[\ldots]^{6}$.

W tym procesie, według Ulickiej, jedną z najistotniejszych ról odgrywają lektury - w eseju pod znamiennym tytułem Чтение. Конец младенчества [Сzytanie. Koniec niemowlęctwa - tłum. M.Ch.] pisarka zauważa, że na ,ja” w dużej mierze składa się suma przeczytanych książek ${ }^{7}$. Podobne założenie zawiera także powieść Zielony namiot. O. Osmuchina zwraca uwagę, że w utworze tym, inaczej niż we wcześniejszych tekstach, pisarka dostrzega w obcowaniu z literaturą część strategii przechodzenia od dzieciństwa do dojrzewania, a nie na przykład środek do odnalezienia siebie czy pozór prawdziwego życia ${ }^{8}$. Proces dojrzewania w powieści Zielony namiot ukazany jest jako inicjacja nie w wymiarze fizycznym, lecz moralnym. Jeden z bohaterów powieści, nauczyciel Wiktor Juliewicz, próbuje odpowiedzieć na pytanie, na czym polega dorosłość: „To nie tylko zdolność rozmnażania się. Może odpowiedzialność za własne postępowanie? Samodzielność? Stopień uświadomienia?" . Oprócz dociekania istoty dojrzałości Wiktor Juliewicz stawia także pytania o sposób, w jaki dokonuje się przejście od dzieciństwa do życia dorosłego. Pragnąc zrozumieć tę przemianę, odwołuje się do cyklu rozwojowego owadów, składającego się z kilku zasadniczych etapów: od larwy poprzez poczwarkę do formy dojrzałej, czyli imago.

Głupiutcy malcy, ludzkie larwy, przyswajają każdą strawę, jaką im się podrzuca, ssą, przeżuwają, połykają wszystkie kolejne wrażenia, potem się przepoczwarzają i wewnątrz poczwarki wszystko układa się w odpowiednim porządku, kształtuje w sposób celowy wyrabiają się odruchy, przyswajają nawyki i podstawowe wyobrażenia o świecie (s. 90).

6 Л. Улицкая, op. cit.

7 Ibid.

${ }^{8}$ О.Ю. Осьмухина, Специифика воплощчения темьл детства в прозе Л. Улицүкой, „Вестник Нижегородского университета им Н. И. Лобачевского” 2014, № 6, s. 229.

${ }^{9}$ L. Ulicka, Zielony namiot, przeł. J. Redlich, Warszawa 2013, s. 92 . Wszystkie cytaty z powieści na podstawie tego wydania. Numer strony podaję w nawiasie po cytacie. 
„Strawa”, którą podrzucał swoim „głupiutkim malcom” Wiktor Juliewicz, była jednak starannie dobrana - składały się na nią największe dzieła literatury rosyjskiej, i to w dużej mierze dzięki niej dokonywał się proces dojrzewania chłopców: ,,poprzez sieroctwo, krzywdy, okrucieństwa i samotność, do percepcji rzeczy, które sam uważał za zasadnicze - uświadomienia dobra i zła, rozumienia miłości jako wartości najwyższej” (s. 94).

Literatura może sprowokować proces moralnego i intelektualnego dojrzewania chłopców: „takim inicjatorem może stać się nawet książka, która w odpowiednim momencie wpadnie w ręce" (s. 121), dokonującego się równolegle do dojrzewania fizycznego.

[...] chłopców stopniowo wypełniał testosteron, najstarszym wyrastały włoski w miejscach intymnych, pojawiały się pryszcze na czole, wszystko swędziało, łamało, ćmiło [...]. Micha wyślizgiwał się do kuchni i czytał pod wspólną żarówką ile wlezie [...]. Siedział, skubiąc twarde pryszcze, z książką dla młodzieży, która nie miała nic wspólnego z niepokojem jego ciała (s. 36).

Obok literatury funkcję wspierającą i w niektórych wypadkach przyspieszającą proces dochodzenia do dojrzałości pełnią gwałtowne wydarzenia, mające charakter przełomowy i inicjacyjny zarazem ${ }^{10}$. Inicjacja w Zielonym namiocie jest umowna - nie odbywa się według ściśle określonych reguł, nie jest sformalizowana, a zachowań bohaterów nie da się określić jako przewidywalnych i stereotypowych. Przeciwnie - mają one jednostkowy i za każdym razem unikalny charakter, mimo to jednak w sekwencji zdarzeń dostrzegalne są elementy upodabniające je do rytualnej inicjacji. Przede wszystkim na skutek tych wydarzeń dochodzi do „społecznie doniosłych aktów”" ści - przejście do kolejnego etapu życia, przybliżającego do dorosłości. Ponadto rodzaj i następstwo zdarzeń składających się na ów przełomowy akt wykazują podobieństwo do tzw. obrzędów przejścia, w których na ogół wyodrębnia się trzy fazy: fazę separacji, fazę marginalizacji i wreszcie fazę włączenia. Najistotniejsze znaczenie dla ostatecznego efektu ma faza druga, podczas której intensyfikują się działania symboliczne - ich celem jest podkreślenie zachodzącej zmiany statusu społecznego ${ }^{12}$. W zakres tych działań mogą wchodzić na przykład „okaleczenia, sprawdziany siły, wytrzymałości, odosobnienie"'13. Często istotną rolę podczas obrzędów inicjacyjnych odgrywa ,przeżycie symbolicznej śmierci [...] oraz duchowe zmartwychwstanie na wyższym poziomie"14. Natomiast przyjęcie w obręb nowej grupy społecznej jest połączone z powrotem do tzw. normalnego życia. Towarzyszą mu, podkreślające doniosłość zaistniałego faktu, działania symboliczne, w tym „obrzędy oczyszczeń i ablucji, przywdzianie odpowiedniego stroju,

${ }^{10}$ Osmuchina za Ulicką pisze o „inicjacji moralnej” („нравственная инициация”). Zob. О.Ю. Осьмухина, ор. cit., s. 229.

${ }^{11}$ Rytuat [w:] Obyczaje, języki, ludy świata, red. S. Żurawski, Warszawa 2007, s. 672.

${ }_{12}$ Zob. Obrzędy przejścia [w:] Obyczaje, języki..., s. 528.

${ }^{13}$ Ibid., s. 530.

${ }^{14}$ Inicjacja [w:] Leksykon symboli, oprac. M. Oesterreicher-Mollwo, przeł. J. Prokopiuk, Warszawa 1992, s. 52. 
zmiana sposobu zachowania"15. W przypadku powieści Ulickiej dodatkowymi „aktorami” biorącymi udział w przełomowych dla bohaterów wydarzeniach są rzeczy ${ }^{16}$. One też w dużym stopniu są sprawcami ${ }^{17} \mathrm{i}$ inicjatorami tych zdarzeń.

Podobieństwo do przywołanego wyżej schematu obrzędu przejścia wyraźnie dostrzec można w podziemnej wędrówce szóstoklasisty Ilii, wymuszonej przez dramatyczne okoliczności zaistniałe w Moskwie wkrótce po śmierci Stalina. Chcąc udokumentować uliczne wydarzenia i reakcje tłumu, bohater, wyposażony w aparat fotograficzny, wyrusza w miasto, jednak splot nieoczekiwanych i groźnych sytuacji powoduje, że ekscytująca wyprawa zamienia się w dramatyczną walkę o przeżycie, w której młody człowiek jest zdany wyłącznie na swoje siły i spryt. Wędrówka Ilii obfituje w elementy symboliczne, składające się na swoisty obrzęd przejścia. Wielogodzinna droga, jaką przebywa chłopiec, uwięziony w podziemnych kanałach Moskwy, spełnia wymagania odosobnienia, jest prawdziwym sprawdzianem siły i wytrzymałości, zarówno fizycznej, jak i duchowej.

Kręta i pełna niebezpieczeństw droga rozpoczyna się od zderzenia ze śmiercią. Pierwszym zadaniem, stojącym przed Ilią, jest pokonanie przeszkody w postaci szeregu trolejbusów, szczelnie ustawionych wzdłuż moskiewskich ulic. Od powodzenia pierwszego wyzwania zależy utrzymanie się przy życiu:

Ludzie wpadali na trolejbusy, kilka osób leżało nieruchomo, inni po nich deptali. Żeby się dostać na chodnik, Ilja musiał się przecisnąć między ciałami - martwymi? [...] Zdawał sobie sprawę, że od razu musi się znaleźć pod brzuchem trolejbusu, bo inaczej zostanie rozmazany po jego ściance (s. 76).

Trolejbusy występują tu w roli milczącego i nieruchomego, ale śmiertelnie niebezpiecznego przeciwnika. Użyta w odniesieniu do martwej ze swej natury rzeczy metafora „brzuch trolejbusu” niejako nadaje tej rzeczy cielesność i ożywia ją, co z kolei wzmaga poczucie zagrożenia, gdyż stwarza wrażenie potencjalnej groźnej aktywności.

Po pierwszej próbie następują kolejne, nie mniej ryzykowne. Wśród nich na uwagę zasługuje spotkanie z wrzeszczącą , pijaną babą w czerwonym szlafroku”18. Barwa szlafroka w połączeniu $\mathrm{z}$ podniesionym głosem kobiety jest wyraźnym sygnałem ostrzegawczym i zagrożeniem samym w sobie. Jednocześnie czerwień stanowi barwę obiecującą ,,przełom i nowe życie"19 i dobrze koresponduje z dokonującą się właśnie w życiu bohatera przemianą.

Kolejną postacią, która staje na drodze Ilii, jest głuchoniemy staruszek, wskazujący chłopcu drogę wyjścia z zablokowanego domu poprzez kotłownię. Mimo że drzwi do pomieszczenia okazują się zamknięte, kotłownia staje się początkiem kolejnego etapu samotnej i ryzykownej podróży bohatera:

15 Obrzędy przejścia..., s. 528.

${ }^{16}$ Obszernie na temat nierozerwalnego związku rytuału i rzeczy, a także o możliwościach szerszego spojrzenia na sferę rytuału i rytualności pisze J. Barański. Zob. J. Barański, op. cit., s. 109-122.

17 Według A. Gella pod pojęciem ,sprawczości” rzeczy kryje się ich zdolność do wywoływania zmian przyczynowych w ich (sprawców) otoczeniu społecznym. Zob. A. Rybus, op. cit., s. 29-33.

18 L. Ulicka, op. cit., s. 78.

${ }^{19}$ Czerwień [w:] Leksykon symboli, s. 27-28. 
[...] wlazł na dach kotłowni, z niego przedostał się na murek i zeskoczył na pusty chodnik, odcięty od tłumu przez oddziały ochronne [...]. I od razu uświadomił sobie, że popełnił błąd, lepiej było siedzieć w bramie (s. 79).

Wydostając się z zablokowanego domu na ulicę, Ilia wpada w następną pułapkę: tłum, który porywa chłopca, może go zmiażdżyć, a on sam może podzielić los martwego mężczyzny ze zmasakrowaną twarzą, w pozycji stojącej przyciśniętego do ulicznego słupa. Po raz kolejny więc Ilia oko w oko staje z czyjąś śmiercią i jednocześnie sam jest jej bardzo bliski. W tym momencie kończy się „naziemna” część wędrówki bohatera i rozpoczyna się jej etap podziemny, będący metaforą zejścia do krainy śmierci. Mozolna przeprawa przez sieć kanałów i podziemnych korytarzy jest metaforą zstąpienia do Hadesu, królestwa ciemności. Wielokrotne, nieudane próby wydostania się na zewnątrz przez przyspawane na stałe żelazne kraty przypominają próby wyjścia z symbolicznego labiryntu, a właśnie przejście przez labirynt niejednokrotnie było częścią składową rytuałów inicjacyjnych, „symbolizowało ono zarówno znajdowanie duchowego centrum, jak i wychodzenie z ciemności na światło" 20 .

Próby opuszczenia wilgotnych i ciemnych podziemi ostatecznie kończą się powodzeniem. Ilia wychodzi na powierzchnię już jako inny człowiek. Dzięki swojej determinacji, właściwym decyzjom, fizycznej sprawności i wytrzymałości kilkakrotnie udaje mu się uniknąć śmierci i szczęśliwie opuścić „otchłań”. Wyjście z podziemnego labiryntu potwierdza zwycięstwo w próbie, jakiej poddany został bohater:

[...] zobaczył kratę, przez którą przechodziło jasnożółte światło. Wspiął się po chybotliwych klamrach, dotknął jej, a ona łatwo się otworzyła. Wyszedł i stwierdził, że stoi pod latarnią w podwórzu domu, gdzie mieszka Sania Stiekłow (s. 81-82).

Moment „wyjścia z ciemności na światło”, który w powieści ma wymiar dosłowny, to zakończenie najważniejszej fazy w obrzędzie przejścia - fazy marginalizacji, w ramach której bohater znajdował się w sytuacji zawieszenia pomiędzy dzieciństwem a dorosłością. Faza włączania do nowej grupy społecznej rozpoczyna się, gdy Ilia przestępuje próg mieszkania Anny Aleksandrowny. Powrotowi do normalnego życia, podobnie jak podczas obrzędów inicjacyjnych, towarzyszą ablucje, przybierające formę oczyszczającej kąpieli: „Anna Aleksandrowna [...] rozebrała Ilię, z pomocą sąsiada zaniosła do łazienki i zaczekała, aż otworzył oczy. Potem umyła go ogromną kosmatą rękawicą, ostrożnie omijając krwiaki" (s. 82). Po oczyszczeniu następuje przywdzianie specjalnego stroju - Ilia zostaje przebrany w damską nocną koszulę. Podstawowy powód takiego przebrania jest prozaiczny: pod dachem Anny Aleksandrowny nie mieszkają mężczyźni (Sania wciąż jeszcze jest dzieckiem i dobrze zdaje sobie z tego sprawę, kiedy porównuje swoje ciało z ciałem śpiącego przyjaciela - Ilii), a więc w domu brakuje męskich ubrań, ale nieco przewrotnie to właśnie damska koszula nocna poprzez efekt kontrastu podkreśla męskość Ilii. Obrazu przemiany chłopca w mężczyznę (wprawdzie jeszcze nie całkowitej, ale już widocznej) dopełnia zdumienie Anny Aleksandrowny, która spostrzega, że ,ten chudziutki chłopiec o zupełnie dziecię-

${ }^{20}$ Labirynt [w:] Leksykon symboli, s. 81. 
cej twarzy jest tak dobrze wyposażony do męskiego życia” (s. 82), a także zakłopotanie Sani, wynikające ze świadomości, że „Ilja jest już mężczyzną, świadczył o tym nie tylko ciemny meszek pod nosem, ale też ścieżka włosów biegnąca w dół brzucha do dorodnego, wielkiego członka" (s. 82).

Kluczową rolę $\mathrm{w}$ procesie inicjacji bohatera odgrywa aparat fotograficzny FED. To on jest sprawcą i inspiratorem przełomowej eskapady Ilii, wynikającej z jego fascynacji możliwościami oferowanymi przez fotografię. Otrzymany w prezencie od ojca aparat rozbudza w chłopcu pasję i potrzebę utrwalania ważnych wydarzeń: „stary aparat zrobił z Ilji fotografa” (s. 35), ,zmienił jego życie” (s. 34), „obudził w Ilji talent” (s. 34; wyróżn. - M.Ch.). Wyróżnione czasowniki jednoznacznie wskazują, która ze stron jest aktywna, kto jest podmiotem w relacji rzecz-człowiek. Zdania te równocześnie podkreślają ścisłą relację pomiędzy bohaterem a przedmiotem. Aparat częściowo jest współodpowiedzialny za ryzyko, jakiego podejmuje się Ilia. Z drugiej strony chłopiec również czuje odpowiedzialność za rzecz, w której posiadanie wszedł - aparat staje się dla niego czymś więcej niż tylko rzeczą - to już nie FED-S, ale „Fiedia”. Nadając mu imię, Ilia upodmiotowia przedmiot, o który od tej pory będzie się troszczył jak o żywą istotę: „Cały czas pamiętał o «Fiedi», jak pieszczotliwie nazywał swój aparat fotograficzny - żeby nie zgnieść obiektywu” (s. 76); „bał się już nie tylko o Fiedię, który po uderzeniu o słup mógł się rozbić w drobny mak” (s. 79); „Ręce przyciskał do brzucha, gdzie pod paskiem od spodni spoczywał ocalony «Fiedia»" (s. 82). Ponadto aparat Ilii jest nie tylko „użyteczną”, ale i ,wierną" rzeczą (s. 33), a cecha ta sytuuje go tyleż w świecie przedmiotów, ile w świecie istot żywych i świadomych.

Przedmioty, jak powiedziano wyżej, jako nieodłączny element uczestniczą w procesie inicjacyjnym pozostałych dwóch głównych bohaterów powieści Ulickiej, albo przynajmniej są głównym sprawcą momentu zwrotnego, ważącego na ich dalszym życiu. W przypadku Michy takim przedmiotem są łyżwy. Wyróżnia je amerykańskie pochodzenie oraz fakt, że posiadają swoistą biografię, mocno splecioną z biografią wuja, który w 1919 roku jako emisariusz Kominternu zakładał w Stanach Zjednoczonych partię komunistyczną. Przed powrotem do kraju po udanej misji zakupił dla członków rodziny kilka kosztownych prezentów: dla żony czerwoną haftowaną sukienkę i czerwone pantofle, a dla synka łyżwy. Były kupione na wyrost, ale syn nie zdążył z nich skorzystać - wkrótce zmarł, a łyżwy ,przeleżały dziesięć lat w schowku, aż trafiły do syna młodszej siostry cioci Gieni. Teraz po dalszych dwudziestu latach, przeszły do rąk - właściwie do nóg - innego krewnego" (s. 21).

Przedmiot, przez kilka dziesięcioleci towarzyszący rodzinie, przechowujący pamięć o jej nieżyjących już członkach, traktowany był przez ciocię Gienię z wielką estymą: „Ciocia Gienia traktowała łyżwy jak rodzinną relikwię” (s. 19), i choć ich wartość materialna już znacznie zmalała, to dla bohaterki porównywalna była z brylantami. Dlatego ofiarowanie ich Misze było dowodem zaufania, jakim ciotka darzyła swojego młodego krewniaka, włączało go w aktywne uczestnictwo w historii rodziny, a także podkreślało jego odpowiedzialność i względną dojrzałość. O tym, że Micha zrozumiał doniosłość wydarzenia, jakim było wręczenie mu tego cennego daru, świadczy napisany przez niego z tej okazji wiersz. 
Amerykańskie łyżwy w krótkim czasie stały się obiektem pożądania szkolnych kolegów Michy, a następnie padły łupem dwóch z nich. Chłopiec nie oddał ich jednak bez walki. Pogoń, w jaką rzucił się za napastnikami, nie wynikała tylko z pragnienia ocalenia rzeczy rzadkiej, trudnodostępnej w radzieckich realiach, albowiem „Nikt nie miał takich łyżew, wszyscy przykręcali do walonek jakąś tandetę” (s. 39). Była też uzasadniona odpowiedzialną postawą Michy, świadomego pozamaterialnej wartości łyżew. Co jednak najważniejsze, stanowiła próbę uchronienia istotnej części własnej tożsamości, związanej z przynależnością do określonej wspólnoty, jaką jest rodzina - dla Michy szczególnie ważna, bo przecież ani nie miał on rodziców, ani nawet ich nie pamiętał. Pościg ma tragiczny finał - jeden ze złodziejaszków ginie pod kołami tramwaju. W wypadku ginie także jedna $\mathrm{z}$ łyżew. Tę, która ocalała, Micha podnosi i zabiera z miejsca wypadku, ale przed domem porzuca. Jego gest jest zrozumiały - jedna łyżwa nie nadaje się do użytku, ale oprócz tego oczywistego wytłumaczenia jest jeszcze jedno: chłopiec bierze odwet na rzeczy, która przyczyniła się do śmierci kolegi, i w ten sposób wskazuje właściwego sprawcę wypadku. Na dowód dodaje: „Ja tego nie chciałem” (s. 41). Po tym, jak Micha stał się świadkiem śmierci, a w swoim przekonaniu również jej mimowolnym sprawcą, jest już innym człowiekiem. Ta śmierć składa się na jego własne życiowe doświadczenie i - jak każda - oddala od dzieciństwa oraz przyspiesza emocjonalne dojrzewanie.

W życiu Sani Stiekłowa rzecz również jest znaczącym elementem procesu dojrzewania, ale mimo że w jego przypadku proces ów przebiega mniej burzliwie niż u przyjaciół (Sania najdłużej z nich zachowuje dziecięcą naturę), nie jest pozbawiony dramatyzmu. Przed Sanią rysuje się kariera pianisty. Jest on wrażliwym, utalentowanym chłopcem o łagodnym usposobieniu, skłonnym do idealistycznych porywów. Jeden z takich właśnie porywów całkowicie przekreśli nadzieje na artystyczną karierę Sani. Chcąc ratować przyjaciela przed napaścią szkolnych chuliganów, chłopiec chwyta ostrze noża trzymanego przez jednego z napastników. Napaść udaje się Sani udaremnić, ale konsekwencje tego czynu zaważą na całym jego życiu: rozcięte ścięgna dłoni uniemożliwią mu dalszą grę na pianinie. Jest to wydarzenie, po którym Sania znacznie dojrzalej i z większą świadomością zaczyna myśleć o swoim obecnym życiu i swojej przyszłości.

We wszystkich przywołanych wydarzeniach główne role odgrywają ludzie, jednak przy bardzo wyraźnym uczestnictwie rzeczy. Ranga przedmiotów jako elementów sprawczych zostaje podkreślona przez ich zindywidualizowanie, które autorka powieści osiąga dzięki krótkim, ale pełnym znaczeń opisom. I tak aparat fotograficzny Ilii to:

FED-S, przedwojenny, zrobiony rękami chłopców z komuny pracy imienia Dzierżyńskiego, będący wierną kopią niemieckiej leiki. Ojciec bardzo cenił ten stary aparat. Kiedy podczas wojny był korespondentem, niemal przez trzy lata woził go ze sobą - a teraz podarował jedynemu synowi (s. 32).

Aparat jest wprawdzie przedmiotem masowej produkcji, ale słowa „zrobiony rękami chłopców z komuny pracy imienia Dzierżyńskiego" powodują, że banalność i anonimowość, wpisane w jego naturę, ustępują przekonaniu o jego wyjątkowości. Słowa te jednocześnie wskazują na obecny od początku istnienia tego przedmiotu związek z człowiekiem. Z kolei łyżwy Michy: 
Była to amerykańska hybryda, która już dawno wyszła z użytku, coś pośredniego między „śnieżynkami” a „gagami”, z podwójnymi płozami i karbowanym noskiem. Łyżwy były przymocowane wielkimi gwiaździstymi nitami do znoszonych butów w kolorze niegdyś czerwonym. Na metalowej płytce łączącej ostrza z butami można było odczytać „Einstein” oraz kilka niezrozumiałych cyfr i liter... Buty były mocno poobijane przez byłego właściciela, ale same łyżwy lśniły jak nowe (s. 19).

Zarówno w odniesieniu do aparatu, jak i łyżew ważny jest ich aspekt materialny, fizyczny, ale również i ten wykraczający poza ich ,przedmiotowość”: i aparat, i łyżwy mają swoją przeszłość - swoistą minibiografię, sytuującą je pomiędzy światem rzeczy a światem ludzi. Nóż na tle tych przedmiotów wyróżnia się lapidarnością opisu: „,składany nóż, podobny do scyzoryka, ale dużo większy z cienkim ostrzem" (s. 28), i brakiem własnej biografii, lecz ten brak równoważy moc kształtowania biografii bohatera.

Powyższe przykłady ukazują, że w powieści Ulickiej rzeczy wykraczają poza sferę materii nieożywionej - biernej i podporządkowanej człowiekowi. Nie tracąc swojej pierwotnej użyteczności i służebności względem człowieka (aparat fotograficzny Ilii służy dokumentowaniu ważnych dla niego wydarzeń i sytuacji, Micha jeździ na łyżwach i ma nad nimi tę władzę, że może je wyrzucić) ${ }^{21}$, bywają personifikowane, mają swoją biografię i, co najistotniejsze, są elementem działającym oraz - choć ich działania są nieintencjonalne - sprawczym. Ich sprawczość wyraża się $\mathrm{w}$ kształtowaniu postaw bohaterów, ingerowaniu w ich przyszłość i aktywnym uczestnictwie w procesie ich dojrzewania.

\section{Bibliografia}

Barański J., Świat rzeczy. Zarys antropologiczny, Kraków 2007.

Leksykon symboli, oprac. M. Oesterreicher-Mollwo, przeł. J. Prokopiuk, Warszawa 1992.

Ludzie w świecie przedmiotów. Przedmioty w świecie ludzi, red. A. Rybus, M.W. Kornobis, Warszawa 2016.

Obyczaje, języki, ludy świata, red. S. Żurawski, Warszawa 2007.

Ulicka L., Zielony namiot, przeł. J. Redlich, Warszawa 2013.

Осьмухина О.Ю., Специфика воплощения темы детства в прозе Л. Улицкой, „Вестник Нижегородского университета им Н.И. Лобачевского” 2014, № 6, s. 227-231.

Улицкая Л., Священный мусор, http://bookz.ru/authors/ludmila-ulickaa/sva6enni_471/page-8-sva6enni_471.html (dostęp: 12.02.2017).

${ }^{21} \mathrm{O}$ złożoności zagadnienia, jakim jest działanie sprawcze na linii rzecz-człowiek, pisze J. Barański: „[...] z jednej strony rzeczy wpływają na charakter jednostek i grup, mogą także przyprawić człowieka o irytację lub egzaltację, sprawić, że poczuje swą siłę lub słabość. $Z$ drugiej strony, to przecież człowiek przypisuje do pewnego stopnia rzeczom znaczenie, zachwycając się jednymi, wzdragając zaś przed innymi, modląc się do jednych, a wyrzucając inne na śmietnik. Zawsze jednak ujawnia się proporcja tych dwóch składników, człowiek-rzecz, w konstytuowaniu znaczenia. W praktyce kulturowej są one nierozróżnialne, pozostają w pewnym dynamicznym wzajemnym zdeterminowaniu". J. Barański, op. cit., s. 108-109. 